PRACE NAUKOWE UNIWERSYTETU EKONOMICZNEGO WE WROCLAWIU

\title{
Agnieszka Skowronek-Grądziel
}

Wyższa Szkoła Oficerska Wojsk Lądowych we Wrocławiu

e-mail: a.skowronek-gradziel@wso.wroc.pl

\section{REJONIZACJA PAŃSTW UNII EUROPEJSKIEJ ZE WZGLĘDU NA WYKORZYSTANIE INTERNETU W DZIALALNOŚCI PRZEDSIĘBIORSTW}

\section{ZONING OF THE EUROPEAN UNION COUNTRIES ON THE GROUNDS OF INTERNET USE IN THE CORPORATE BUSINESS ACTIVITIES}

DOI: $10.15611 /$ pn.2017.477.22

JEL Classification: F, O, R

\begin{abstract}
Streszczenie: Celem artykułu było wyodrębnienie rejonów Unii Europejskiej o podobnych wzorcach wykorzystania Internetu w działalności przedsiębiorstw. W pracy pojęcie „region” zdefiniowano jako obszar sąsiadujących ze sobą państw, o zbliżonym poziomie rozwoju, opisanym wartościami zmiennych diagnostycznych. Wiedza na temat kształtowania się rejonów może mieć znaczenie nie tylko poznawcze, ale i praktyczne, przydatne w trakcie planowania oraz zarządzania przestrzennego. W głównej hipotezie pracy założono, iż Unia Europejska w badanym obszarze jest zróżnicowana przestrzennie. Badania przeprowadzone zostały z wykorzystaniem metod wielowymiarowej analizy porównawczej. Głównym źródłem wiedzy o przedmiocie badawczym były dane z Europejskiego Urzędu Statystycznego. Na podstawie uzyskanych wyników potwierdzono prawdziwość weryfikowanej w pracy hipotezy badawczej. Stwierdzono, iż w Europie widoczny jest podział na dobrze skomunikowane rejony północne i zachodnie oraz słabiej skomunikowane Południe. Internet najmniej wykorzystywany jest w działalności przedsiębiorstw z państw zlokalizowanych na wschodniej i południowowschodniej granicy Unii Europejskiej.
\end{abstract}

Słowa kluczowe: rejony Unii Europejskiej o podobnych wzorcach wykorzystania Internetu, wykorzystanie Internetu w przedsiębiorstwach, stopień skomunikowania przedsiębiorstw, zróżnicowanie przestrzenne ze względu na wykorzystanie Internetu.

Summary: The aim of this article was to distinguish zones of the European Union with similar patterns when it comes to using Internet for their business activities. The knowledge on the zone formation, meaning neighbouring countries here, with a comparable level of development described by diagnostic variables, can be of cognitive significance as well as practical, which would be useful while planning and managing area development. The main hypothesis was founded on the thesis that the European Union was spatially diversified in the area taken into consideration. The research was conducted using a multidimensional method of comparative analysis using data from the year 2014, and the main source of knowledge on the sub- 
ject of study was Eurostat. The results of the research have proved that the hypothesis is true. It has been proved that in Europe the division into north and west regions with good communication and east region with worse communication is visible. Internet is used relatively more rarely by companies operating in countries located in eastern and south-eastern border of the European Union.

Keywords: zones within European Union with similar patterns of Internet use, use of Internet by corporations, degree of business communication by and within companies, spatial diversity because of Internet use.

\section{Wstęp}

Celem polityki regionalnej państw Unii Europejskiej (UE) w latach 2014-2020 jest wsparcie wzrostu gospodarczego w rezultacie zwiększenia spójności ekonomicznej regionów. Jednym z priorytetów działania jest zwiększanie dostępności, stopnia zastosowania i jakości technologii informacyjno-komunikacyjnych ${ }^{1}$.

Opierając się na założeniach wspomnianej polityki regionalnej, postawiono weryfikowaną w toku pracy hipotezę badawczą, iż UE na płaszczyźnie wykorzystania Internetu $\mathrm{w}$ działalności przedsiębiorstw jest zróżnicowana przestrzennie.

$\mathrm{Na}$ tym tle nadrzędnym celem artykułu stało się wyodrębnienie rejonów UE o podobnych wzorcach rozwiązań w analizowanym obszarze. Pojęcie „rejon” zdefiniowane zostało jako terytoria sąsiadujących państw, o zbliżonym poziomie rozwoju, opisanym wartościami zmiennych diagnostycznych [Nowak 1990, s. 115]. $\mathrm{W}$ takim rozumieniu rejon tworzyły również państwa, których granicą było morze, np. państwa zlokalizowane w basenie Morza Sródziemnego.

Do wyodrębnienia zwartych przestrzennie rejonów posłużyły wyniki badań, w trakcie których zastosowane zostały metody wielowymiarowej analizy porównawczej (WAP), w szczególności hierarchicznej procedury aglomeracyjnej za pomocą metody Warda oraz porządkowania liniowego za pomocą metody wzorca rozwoju ${ }^{2}$. Pogłębiając zakres prowadzonych badań, miary rozwoju zestawiono w relacji do PKB per capita wyrażonego w parytecie siły nabywczej w euro.

Główne źródło wiedzy o przedmiocie badawczym stanowiły informacje z Europejskiego Urzędu Statystycznego - Eurostatu (ESO).

Zdobyta wiedza ważna jest dla decydentów z obszaru europejskiej polityki regionalnej. Znajomość czynników, na gruncie których występuje zróżnicowanie przestrzenne, pozwala kompleksowo spojrzeć na problem, świadomie określać cele i w rezultacie podejmować trafne decyzje, które przełożą się na zniwelowanie różnic rozwojowych między rejonami. Artykuł ma mieć zatem znaczenie poznawcze i praktyczne.

${ }^{1}$ Polityka regionalna stanowi element polityki spójności UE - unijnej strategii rozwoju państw członkowskich i regionów; obecnie wdrażana obejmuje lata 2014-2020 [Urząd Publikacji UE 2015, s. 207].

2 Metoda służy do uporządkowania obiektów w kolejności zgodnej ze wzrostem zjawiska złożonego. Na potrzeby badań zaadaptowana została do podziału państw na grupy. 


\section{Dobór cech diagnostycznych}

Przedmiotem badań było wyodrębnienie z dwudziestu ośmiu państw UE zwartych przestrzennie rejonów o podobnych wzorcach wykorzystania Internetu w działalności przedsiębiorstw. Rejonizację przeprowadzono na podstawie wyników z badań wykonanych z zastosowaniem metod WAP. W użytych metodach zakłada się, iż wytypowane do badania zmienne muszą spełniać kryteria merytoryczne i formalne [Tarka 2010, s. 197-202; Walesiak 2004, s. 54-55; Nowak 1990, s. 23-28]. W toku procedury kwalifikacyjnej określono zatem pięć cech diagnostycznych. Cechy pochodziły z bazy danych $\mathrm{ESO}^{3}$, miały charakter stymulant, ocenione zostały pod kątem przydatności do dyskryminacji analizowanych obiektów oraz były wyrażone w postaci wskaźników ${ }^{4}$. Ostatecznie wybrane zmienne uznano za jeden obszar diagnostyczny określający skomunikowanie przedsiębiorstw (tab. 1).

Tabela 1. Zmienne diagnostyczne określające skomunikowanie przedsiębiorstw państw Unii Europejskiej ostatecznie zakwalifikowane do analiz

\begin{tabular}{|l|l|}
\hline \multicolumn{1}{|c|}{$\begin{array}{c}\text { Symbol } \\
\text { zmiennej }\end{array}$} & \multicolumn{1}{c|}{ Nazwa zmiennej } \\
\hline$X_{1}$ & Dostęp do łącza szerokopasmowego [w \%] \\
\hline$X_{2}$ & E-sprzedaż przez stronę internetową, aplikacje mobilne, wiadomości typu EDI [w \%] \\
\hline$X_{3}$ & $E$-zakupy przez stronę internetową, aplikacje mobilne, wiadomości typu EDI [w \%] \\
\hline$X_{4}$ & Korzystanie z usług w chmurze obliczeniowej [w \%] \\
\hline$X_{5}$ & Zatrudnienie specjalistów ICT [w \%] \\
\hline
\end{tabular}

Źródło: opracowanie własne na podstawie [ESO 2016].

W pracy uwagę skupiono na roku 2014 - pierwszym roku funkcjonowania obecnie wdrażanej polityki regionalnej UE. W kolejnym kroku, w celu określenia, czy obserwowane na płaszczyźnie wykorzystania Internetu w działalności przedsiębiorstw zróżnicowanie przestrzenne państw UE podlega zmianom w czasie, podobną analizę przeprowadzono również na danych z roku $2007^{5}$.

${ }^{3} \mathrm{~W}$ pracy założono, iż skorzystanie ze specjalistycznych danych z Eurostatu stanowi gwarancję zachowania poprawności na gruncie treści.

${ }^{4}$ Zmienne wyrażone w postaci wskaźników, jako odsetek przedsiębiorstw spełniających określone warunki, przypadających na wszystkie poddane badaniu w danym kraju przedsiębiorstwa, były gwarancją porównywalności.

${ }^{5}$ W roku 2007 nie wyznaczano wskaźnika określającego zakup przez przedsiębiorstwa usług w chmurze obliczeniowej. 


\section{Metoda badawcza}

Ze względu na przyjęte do badania charakterystyki wydzielono rejony UE o zbliżonych wzorcach zastosowania Internetu w działalności przedsiębiorstw. W trakcie kwalifikowania państw do rejonów korzystano z klasyfikacji opracowanej w Dziale Statystycznym ONZ. Zadanie zrealizowano na podstawie wyników badań przeprowadzonych przy użyciu metod WAP. Z grupy hierarchicznych procedur aglomeracyjnych wykorzystano metodę Warda, a z obszaru porządkowania liniowego - metodę wzorca rozwoju ${ }^{6}$. Pierwsza metoda służy do określenia podobieństwa bez ustalania hierarchii obiektów. Druga pozwala uszeregować obiekty w kolejności zgodnej ze wzrostem poziomu zjawiska złożonego ${ }^{7}$. Wyodrębniając zwarte przestrzennie rejony, na podstawie wyników metod o odmiennych schematach postępowania starano się sprawdzić, czy uzyskane podziały okażą się zbieżne, dlatego w metodzie wzorca rozwoju podzielono państwa na liczbę grup typologicznych, zgodną z wyznaczoną w metodzie Warda.

W metodzie Warda, stosując współczynnik ilorazu odległości aglomeracyjnych, wyznaczono trzy odmienne pod względem charakteryzujących je na płaszczyźnie dostępu przedsiębiorstw do Internetu cech grupy typologiczne. Do grupy pierwszej trafily państwa, w których dostęp przedsiębiorstw do szerokopasmowego Internetu był wysoki, w granicach od 95 do $100 \%$. Zakupy przez Internet deklarowano w przypadku od 32 do $72 \%$ badanych przedsiębiorstw. Pozostałe przeciętne wartości cech dla poszczególnych obiektów określono jako średnie i wysokie. W grupie drugiej procent przedsiębiorstw z dostępem do szerokopasmowego Internetu również był wysoki, wahał się od 93 do 99\%, e-zakupy zgłosiło między 15 a 32\% badanych przedsiębiorstw, a na płaszczyźnie pozostałych zmiennych wartości były średnie i niskie. W przypadku państw z grupy trzeciej odnotowano najniższe poziomy przyjętych do badania cech.

W metodzie wzorca rozwoju do podziału państw na klasy posłużyły miary rozwoju oszacowane w rezultacie porządkowania obiektów. Do grupy pierwszej trafiły państwa o wysokim stopniu skomunikowania przedsiębiorstw, w których miara rozwoju wahała się od 0,50 do 0,87 . W grupie drugiej znalazły się państwa o przeciętnym stopniu skomunikowania (z miarą rozwoju od 0,31 do 0,47), a w grupie trzeciej o niskim stopniu skomunikowania przedsiębiorstw (od 0,25 do 0,09).

Ostatnią rejonizację państw UE uzyskano, pogłębiając zakres prowadzonych badań o zestawienie dla poszczególnych państw oszacowanych miar rozwoju w relacji do PKB per capita wyrażonego w parytecie siły nabywczej w euro. Zastosowanie do badania wskaźników określających poziom aktywności gospodarczej państw pozwala wyeliminować różnice w poziomach cen między badanymi krajami i w rezultacie

${ }^{6}$ Podobne badanie przeprowadzone za pomocą metody sum standaryzowanych dostarczyło zbieżnych wyników, gdyż współczynnik korelacji rang Spearmana wyniósł 0,99.

${ }^{7}$ Szczegółowe opisy wymienionych metod znajdują się np. w pracach: [Kołwzan, Pieronek 2012; Panek 2009; Nowak 1990]. 
porównania są miarodajne. Na podstawie trzech stopni skomunikowania przedsiębiorstw oraz dwóch przedziałów wartości PKB per capita wyrażonego w parytecie siły nabywczej w euro, gdzie do $100 \%$ poziom wskaźnika jest niższy niż średnia w UE, a wartości $100 \%$ i powyżej oznaczają poziom wyższy niż średnia, ponownie podzielono państwa na grupy. Uzyskana klasyfikacja posłużyła do wyznaczenia rejonów o podobnych wzorcach wykorzystania Internetu w działalności przedsiębiorstw.

Wszelkie obliczenia do pracy wykonywano za pomocą pakietów komputerowych Excel oraz Statistica. Rysunki zamieszczone w artykule opracowano w programie graficznym CorelDRAW.

\section{Wyniki}

\subsection{Rejonizacja państw UE na podstawie wyników klasyfikacji przeprowadzonej przy pomocy hierarchicznej procedury aglomeracyjnej}

Wyodrębnianie zwartych przestrzennie rejonów państw UE rozpoczęto od zastosowania wyników klasyfikacji przeprowadzonej na danych z roku 2014 za pomocą hierarchicznej procedury aglomeracyjnej z wykorzystaniem schematu grupowania J.H. Warda. Z trzech odmiennych pod względem skomunikowania przedsiębiorstw grup państw UE wydzielono siedem rejonów (rys. 1).

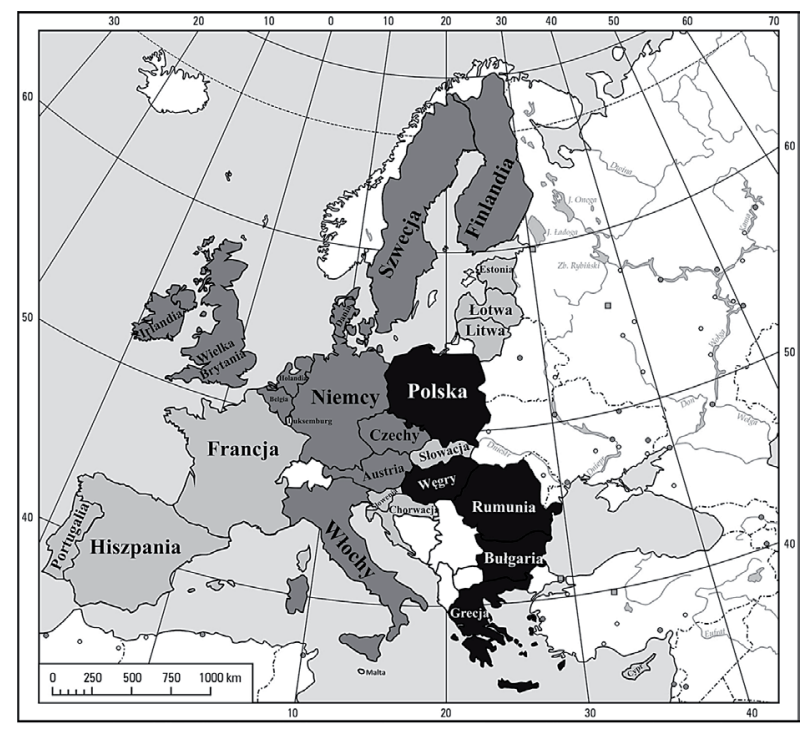

Rys. 1. Rejony UE wydzielone ze względu na zbliżone wzorce wykorzystania Internetu w działalności przedsiębiorstw za pomocą metody Warda, dane z roku 2014 (kolor ciemnoszary - państwa o wysokich poziomach badanych cech, jasnoszary - poziom przeciętny, czarny - niski)

Źródło: opracowanie własne na podstawie [ESO 2016; United Nations Statistics Division 2016]. 
Rejon tożsamy z grupą państw o najwyższych poziomach poddanych badaniom charakterystyk objął zlokalizowane w Europie Północnej państwa skandynawskie: Danię, Szwecję, Finlandię, na Wyspach Brytyjskich: Wielką Brytanię i Irlandię, w Europie Zachodniej: Niemcy, Austrię, Belgię, Holandię i Luksemburg, z Południa Włochy oraz z Europy Wschodniej Czechy.

Z grupy o przeciętnym poziomie analizowanych cech wyłoniono cztery rejony. Jeden stanowiła Słowacja. Do kolejnego rejonu zakwalifikowano Kraje Bałtyckie Litwę, Łotwę i Estonię. Odrębny rejon utworzyły dwa państwa byłej Jugosławii Chorwacja oraz Słowenia. Ostatni rejon objął z zachodu UE: Francję, z południa: Portugalię, Hiszpanię i Maltę oraz Cypr'.

W skład dwóch rejonów o najsłabszym poziomie analizowanych cech weszło pięć państw z wschodniej i południowej Europy. W jednym znalazła się wyłącznie Polska, a w drugim: Węgry, Rumunia, Bułgaria i Grecja.

Dla porównania podobne badanie przeprowadzono na podstawie danych $\mathrm{z}$ roku 2007. Uzyskano wówczas również siedem rejonów, które w stosunku do roku 2014 różniły się jednak pod względem struktury (rys. 2).

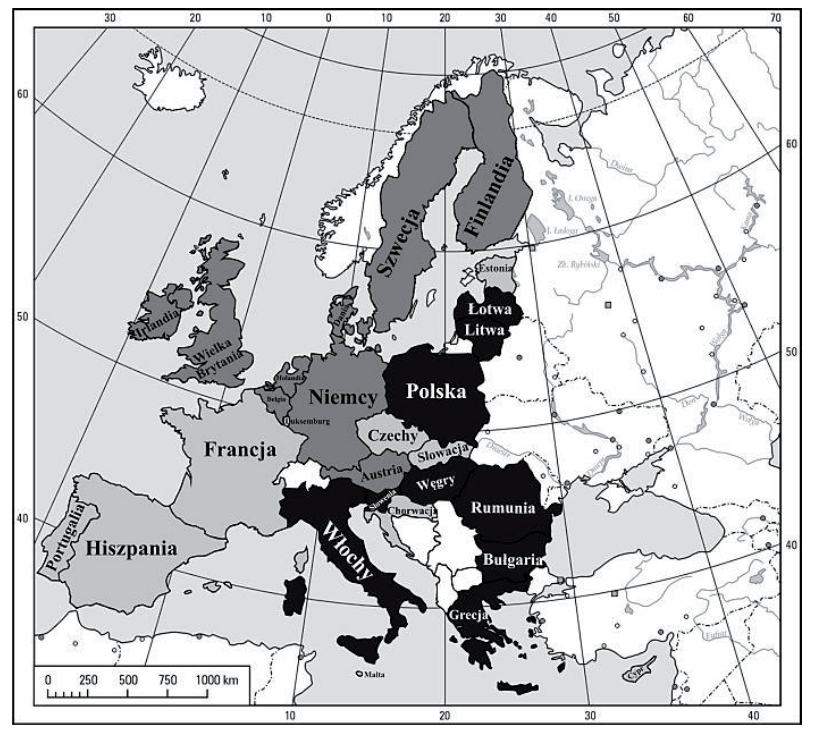

Rys. 2. Rejony UE wydzielone ze względu na zbliżone wzorce wykorzystania Internetu w działalności przedsiębiorstw za pomocą metody Warda, dane z roku 2007 (kolor ciemnoszary - państwa o wysokich poziomach badanych cech, jasnoszary - poziom przeciętny, czarny - niski)

Źródło: opracowanie własne na podstawie [ESO 2016; United Nations Statistics Division 2016].

${ }^{8}$ W klasyfikacji Działu Statystycznego ONZ Cypr zakwalifikowany został do Azji Zachodniej, ale ponieważ od 1 maja 2004 r. jest członkiem UE oraz leży we wschodniej części Morza Śródziemnego, a państwa basenu Morza Śródziemnego stanowią obszar połączony kulturowo, historycznie, politycznie, handlowo i gospodarczo, dlatego w pracy zaproponowano powyższe rozwiązanie. 
W grupie państw o najsłabszym stopniu skomunikowania przedsiębiorstw znalazło się dziewięć obiektów (o pięć więcej niż w roku 2014), przyporządkowanych do dwóch rejonów. Jeden rejon utworzyły zlokalizowane nad Morzem Bałtyckim: Polska, Litwa, Łotwa, które w jednym czasie (1. maja 2004 roku) przystąpiły do UE, a przed transformacją systemową ${ }^{9}$ funkcjonowały w podobnym systemie gospodarki nakazowo-rozdzielczej (w 2014 z trzech państw została tylko Polska). Do kolejnego rejonu trafiły państwa z południa Europy: Włochy, Słowenia, Grecja oraz ze wschodu Europy: Węgry, Rumunia, Bułgaria.

W roku 2007 z dziesięciu przeciętnie skomunikowanych państw UE wydzielono cztery rejony. Jeden rejon stanowiły Czechy i Słowacja (do 1993 roku jedno państwo - Czechosłowacja). Do kolejnych, jednoelementowych rejonów zakwalifikowano kraj bałtycki - Estonię i państwo byłej Jugosławii - Chorwację. Ostatni rejon objął sąsiadujące ze sobą pozostałe państwa z grupy, leżące na zachodzie: Francję i Luksemburg oraz na południu UE: Portugalię, Hiszpanię, Włochy, Maltę i Cypr.

W grupie o najmocniej skomunikowanych przedsiębiorstwach w 2007 roku było dziewięć państw, w tym z Europy Północnej trzy państwa skandynawskie: Dania, Szwecja, Finlandia, dwa z Wysp Brytyjskich: Wielka Brytania i Irlandia oraz z Europy Zachodniej: Belgia, Holandia, Niemcy i Austria (czyli w sumie o dwa państwa mniej niż w 2014 roku).

\subsection{Rejonizacja państw UE na podstawie wyników grupowania przeprowadzonego za pomocą metody wzorca rozwoju}

Kolejną rejonizację państw UE przeprowadzono na podstawie wyników uzyskanych w rezultacie zastosowania metody wzorca rozwoju. Uporządkowane według przyjętych do badania charakterystyk, w kolejności od najmocniejszego do najsłabszego, państwa UE podzielono analogicznie jak w metodzie Warda - na trzy grupy.

Stosując do podziału obiektów metodę wzorca rozwoju, otrzymano pięć rejonów o podobnych wzorcach wykorzystania Internetu w działalności przedsiębiorstw (rys. 3).

Rejon o wysokim stopniu skomunikowania przedsiębiorstw objął jedenaście państw, w tym z Europy Północnej: Danię, Szwecję, Finlandię, z Wysp Brytyjskich: Wielką Brytanię i Irlandię, z Europy Zachodniej: Belgię, Holandię, Luksemburg Niemcy i Austrię oraz z Europy Wschodniej - Czechy.

Państwa o przeciętnym stopniu skomunikowania przedsiębiorstw utworzyły dwa rejony. Do jednego trafiły północnoeuropejskie państwa bałtyckie: Litwa, Łotwa i Estonia. Drugi rejon objął państwa zlokalizowane w południowej części UE: Portugalię, Hiszpanię, Maltę, Włochy, Chorwację, Słowenię, Cypr, w zachodniej Francję oraz we wschodniej: Węgry i Słowację.

${ }^{9}$ W Polsce proces transformacji systemowej rozpoczął się w 1989 roku, a na Litwie i Łotwie w roku 1991. 


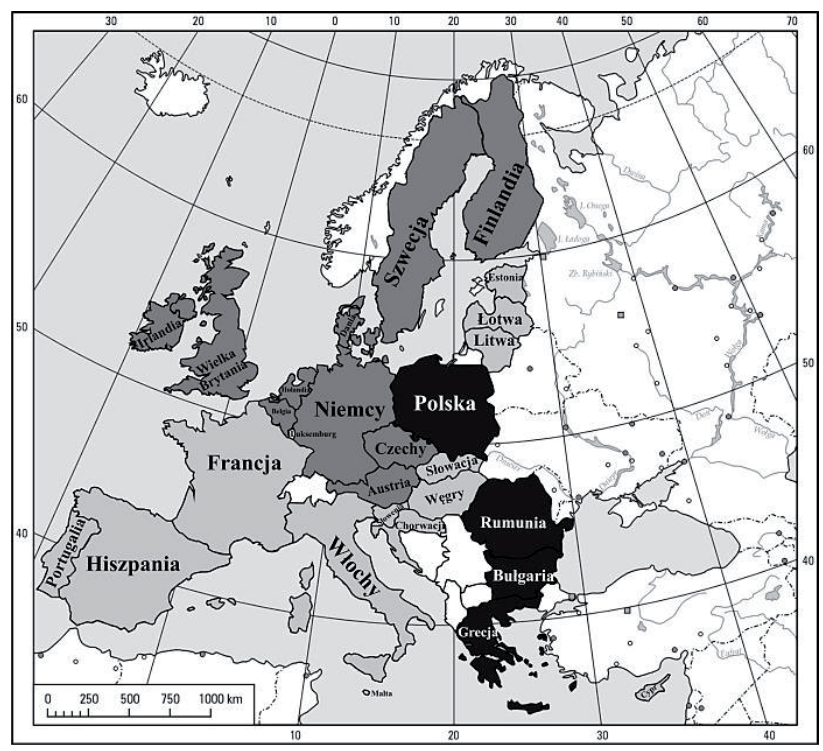

Rys. 3. Rejony UE wydzielone ze względu na zbliżone wzorce wykorzystania Internetu w działalności przedsiębiorstw za pomocą metody wzorca rozwoju, dane z roku 2014 (kolor ciemnoszary - państwa o wysokich poziomach badanych cech, jasnoszary - poziom przeciętny, czarny - niski)

Źródło: opracowanie własne na podstawie [ESO 2016; United Nations Statistics Division 2016].

Państwa o niskim poziomie wykorzystania Internetu w działalności przedsiębiorstw, podobnie jak w przypadku państw o przeciętnym stopniu, utworzyły dwa rejony skomunikowania. W jednym znalazła się Polska, w kolejnym: Rumunia, Bułgaria oraz Grecja.

\subsection{Państwa UE ze względu na miarę rozwoju a PKB per capita w parytecie sily nabywczej w euro}

Wykonując ostatnią rejonizację, zestawiono oszacowane w wyniku zastosowania metody porządkowania liniowego miary rozwoju ze wskaźnikami PKB per capita wyrażonymi w parytecie siły nabywczej w euro. W rezultacie uzyskano pięć grup państw, z których wyłoniono siedem rejonów (rys. 4).

Grupa I utworzyła jeden rejon I, który objął państwa o wysokich stopniach skomunikowania i wartościach PKB per capita wyrażonych w parytecie siły nabywczej w euro wyższych niż średnia europejska. Znalazły się w nim: Austria, Belgia, Dania, Finlandia, Holandia, Irlandia, Luksemburg, Niemcy, Szwecja i Wielka Brytania.

Do grupy II, stanowiącej rejon II, o wysokim stopniu skomunikowania przedsiębiorstw i PKB per capita wyrażonym w parytecie siły nabywczej w euro niższym niż średnia europejska zakwalifikowały się Czechy. 


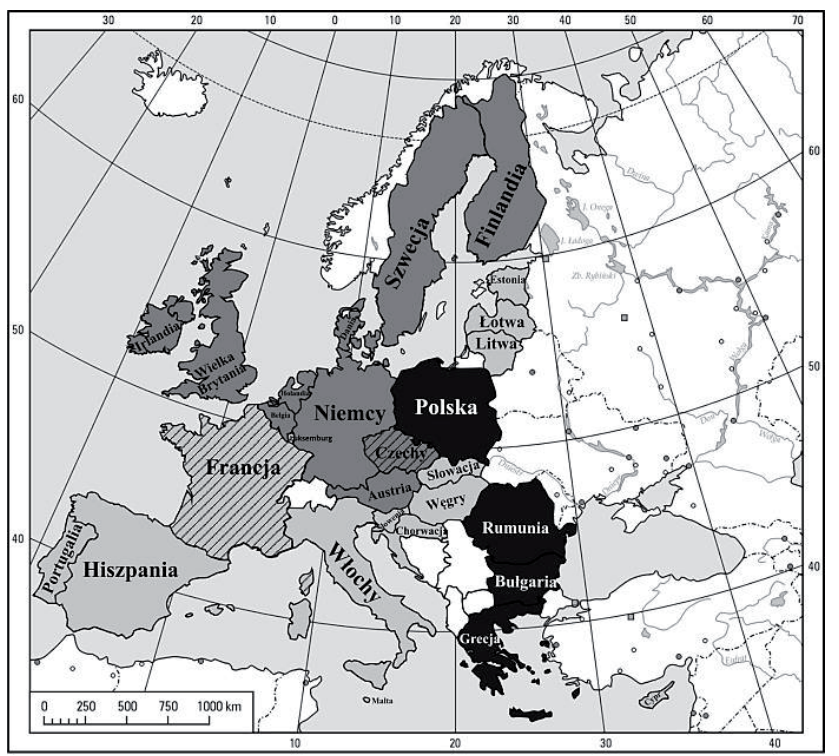

Rys. 4. Rejony UE wydzielone ze względu na zbliżone wzorce wykorzystania Internetu w działalności przedsiębiorstw za pomocą metody wzorca rozwoju i PKB per capita w parytecie siły nabywczej w euro, dane z roku 2014 (kolor ciemnoszary - rejon I, ciemnoszary z fakturą - rejon II, kolor jasnoszary z fakturą - rejon III, jasnoszary - rejony IV i V, czarny - VI i VII)

Źródło: opracowanie własne na podstawie [ESO 2016; United Nations Statistics Division 2016].

Jednoelementową grupę III i rejon III o przeciętnym stopniu skomunikowania oraz wyższym od średniej europejskiej poziomie PKB per capita wyrażonym w parytecie siły nabywczej w euro utworzyła Francja.

Z grupy IV, do której zakwalifikowały się państwa charakteryzujące się przeciętnym stopniem skomunikowania przedsiębiorstw oraz PKB per capita wyrażonym w parytecie siły nabywczej w euro poniżej średniej europejskiej, wyłoniono dwa rejony (IV i V): północny z Litwą, Łotwą i Estonią oraz południowy z Portugalią, Hiszpanią, Włochami, Słowenią, Chorwacją, Słowacją, Maltą i Cyprem oraz z Węgrami.

Ostatnią V grupę z dwoma rejonami (VI i VII) o najniższych wartościach badanych wskaźników utworzyły Bułgaria, Grecja, Rumunia oraz Polska.

\section{Zakończenie}

Wykorzystanie Internetu w działalności przedsiębiorstw państw UE, jak większość zjawisk społeczno-ekonomicznych, charakteryzuje się zróżnicowaniem przestrzennym. W roku 2014, w zależności od zastosowanej metody, w pracy wyodrębniono 5 lub 7 rejonów o różnych wzorcach rozwiązań w analizowanym obszarze.

Uzyskane na podstawie wyników z obydwu metod badawczych rejonizacje uznano za zbieżne. Wniosek o wysokim podobieństwie wyników potwierdzono, sza- 
cując, bez wartościowania cech, unormowany w przedziale [0;1] miernik podobieństwa grupowania obiektów, którego wartość osiągnęła poziom $0,86^{10}$.

W UE stale widoczny jest podział na mocniej i słabiej skomunikowane rejony. Wszystkie państwa zlokalizowane na północy i zachodzie Europy zakwalifikowane zostały do rejonów o wysokim bądź przeciętnym poziomie wykorzystania Internetu w działalności przedsiębiorstw. W przeciwieństwie do Europy Południowej i Wschodniej, na północy i zachodzie UE, nie było żadnego państwa o niskim skomunikowaniu przedsiębiorstw.

Poza przypadkiem Czech, wysoki poziom cech z omawianego obszaru diagnostycznego charakteryzował państwa, w których wartość wskaźnika PKB per capita wyrażonego w parytecie siły nabywczej w euro była powyżej średniej europejskiej - typowy był dla bogatych państw z północnej i zachodniej Europy. Jedynym państwem, które osiągnęło poziom przytoczonego wskaźnika powyżej średniej europejskiej, o przeciętnym stopniu skomunikowania przedsiębiorstw, była Francja. Pozostałe rejony przeciętnie skomunikowane na gruncie przedsiębiorstw zlokalizowane były na południu UE lub stosunkowo niedługo funkcjonowały w realiach gospodarki wolnorynkowej. Podobnie można by określić rejony o najsłabszym stopniu skomunikowania przedsiębiorstw. Po szczegółowej analizie problemu zauważono jednak, iż omawiane rejony stanowiły dodatkowo wschodnią i południowo-wschodnią granicę UE. W tym obszarze nie było ani jednego państwa, dla którego wartość wskaźnika PKB per capita wyrażonego w parytecie siły nabywczej w euro byłaby powyżej średniej europejskiej.

Z przeprowadzonych analiz wynika jednak, że zmienia się struktura badanych rejonów, maleje liczba państw o najsłabszym stopniu skomunikowania przedsiębiorstw, rośnie liczba państw o przeciętnym oraz wysokim poziomie analizowanych cech.

W najbliższym czasie należy się spodziewać, iż zgodnie z założeniami ze strategii państw UE będzie następowało dalsze wyrównywanie różnic rozwojowych. W rezultacie powinno zmniejszać się przestrzenne zróżnicowanie rejonów. Nie należy jednak zapominać, iż wyrównywanie różnic rozwojowych to proces uzależniony od rozwoju gospodarczego państw i postępu technologicznego, czyli zmiennych, dzięki którym systematycznie rośnie liczba przedsiębiorstw korzystających z Internetu i zwiększają się możliwości zastosowania nowych rozwiązań.

\section{Literatura}

ESO, 2016, Statistics A-Z, http://ec.europa.eu (27.07.2016).

Kołwzan W., Pieronek J., 2012, Elementy teorii decyzji, WSOWL, Wrocław.

Mynarski S., 1992, Badania przestrzenne rynku, Wydawnictwo Naukowe PWN, Warszawa.

Nowak E., 1990, Metody taksonomiczne w klasyfikacji obiektów społeczno-gospodarczych, PWE, Warszawa.

${ }^{10}$ Miernik opisany w: [Salamaga 2010, s. 2-3]. 
Panek T., 2009, Statystyczne metody wielowymiarowej analizy porównawczej, SGH, Warszawa.

Salamaga M., 2010, Miernik podobieństwa grupowania obiektów, Wiadomości Statystyczne, nr 6, s. 1 -11. Strahl D. (red.), 2006, Metody oceny rozwoju regionalnego, Wydawnictwo AE, Wrocław.

Tarka D., 2010, Własności cech diagnostycznych w badaniach typu taksonomicznego, Ekonomia i Zarządzanie, $\mathrm{nr}$ 4, s. 194-203.

Traktato funkcjonowaniuUE,2013, Spójność gospodarcza, społecznaiterytorialna, Dz.U.2004.90.864/2, Art. 174, http://eur-lex.europa.eu (21.10.2016).

United Nations Statistics Division, 2016, Composition of macro geographical (continental) regions, geographical sub-regions, and selected economic and other groupings, New York, http://unstats. un.org (21.10.2016).

Urząd Publikacji UE, 2015, Europejskie fundusze strukturalne i inwestycyjne na lata 2014 -2020: Teksty urzędowe i komentarze, Luksemburg, http://ec.europa.eu (27.07.2016).

Walesiak M., 2004, Problemy decyzyjne w procesie klasyfikacji zbioru obiektów, Prace Naukowe Akademii Ekonomicznej we Wrocławiu, Ekonometria nr 13, s. 52-71. 